\title{
ЗНАЧЕННЯ РАЦІОНАЛЬНОГО ХАРЧУВАННЯ ДЛЯ ЗДОРОВ'Я ВАГІТНИХ
}

\author{
Тернопільський національний медичний університет \\ імені І. Я. Горбачевського МОЗ України, м. Тернопіль, Україна
}

\begin{abstract}
Мета: проаналізувати дані літературних джерел щодо особливостей харчування вагітних і визначити його роль у профрілактиці розвитку ускладнень вагітності та здоров"ї майбутньої дитини.

Матеріали і методи. Проведено аналіз літературних джерел щодо особливостей харчування вагітних жінок. Використано бібліосемантичний та аналітичний методи дослідження.

Результати. Для нормального розвитку плода потрібне регулярне та раціональне харчування майбутньої матері з достатньою кількістю макро- і мікроелементів. Особливо підвищується потреба в таких нутрієнтах, як залізо, йод, фолієва кислота, кальцій, магній, цинк, вітамін D тощо. Недостатнє і неповноцінне харчування може призводити не лише до уроджених вад розвитку плода, але й до інших ускладнень гестаційного процесу, таких як прееклампсія, гестаційна гіпертензія, синдром затримки росту плода, передчасні пологи тощо. У наукових літературних джерелах все ще існують протиріччя щодо середнього рекомендованого споживання енергії під час вагітності, кількості додаткового приймання вітамінів та інших макро- і мікронутрієнтів. Для нормалізації харчування усім вагітним необхідно організовувати свій раціон згідно з основними принципами так званої «Тарілки здорового харчування», яка розроблена відповідно до рекомендацій Міністерства охорони здоров'я та Гарвардської школи громадського здоров'я.

Висновки. Раціональне харчування, збалансоване за всіма харчовими продуктами, з необхідною кількістю макро- і мікронутрієнтів, є одним із найважливіших фракторів, необхідних для підтримки здоров'я та забезпечення стійкості організму вагітних жінок до негативного впливу зовнішнього середовища, який дозволить знизити ризик розвитку перинатальної патології, дитячої смертності, зменшити частоту недоношеності та уроджених вад розвитку.
\end{abstract}

КЛЮчОВІ СЛОВА: харчування вагітних; раціональне харчування; дефіцит нутрієнтів; профілактика ускладнень вагітності.

Бажання кожної вагітної - народити здорову дитину. Добре відомо, що більший шанс досягти цього мають фрізично активні жінки, які дотримуються правил здорового харчування, не курять, не вживають алкоголь та мають нормальний індекс маси тіла (IMT) [40]. Серед проблем, що впливають на здоров'я майбутніх матерів, вагоме місце займає організація раціонального харчування. Воно є однією з основних умов сприятливого перебігу і завершення вагітності та пологів, нормального розвитку плода і новонародженого [3]. Встановлено, що харчування та спосіб життя жінок до і під час вагітності та грудного вигодовування мають довгострокові наслідки для подальшого здоров'я дитини, включаючи ризик поширених неінфекційних захворювань, таких як ожиріння, діабет та серцево-судинні захворювання [31]. Головна причина в тому, що вже 3 перших тижнів вагітності починає фрормуватися більшість основних органів малюка. Здорове харчування допомагає створити сприятливі умови для раннього нормального ембріонального розвитку [16]. А для зростаючого плода єдиним джерелом усіх необхідних нутрієнтів (води, білків, жирів, вуглеводів, вітамінів, макро- і мікроелементів) $€$ лише організм матері. При цьому вітаміни і мінерали контролюють процеси запліднення, імплантації, ембріо- і фетогенезу, пологів, лактації і подальшого розвитку дитини $[5,8,21]$.

(c) О. В. Лотоцька, О. Є. Гавліч, 2021
Тому питання про раціональне харчування вагітних залишається актуальним не лише для акушерів-гінекологів, а й для всього суспільства. щоб зачати, виносити і народити здорову дитину, майбутній мамі доведеться дотримуватися правил здорового харчування як у період підготовки до вагітності, так і самої вагітності [11].

Мета роботи: проаналізувати дані літературних джерел щодо особливостей харчування вагітних і визначити його роль у профрілактиці розвитку ускладнень вагітності та здоров'ї майбутньої дитини.

Матеріали і методи. Проведено аналіз літературних джерел щодо особливостей харчування вагітних жінок. Використано бібліосемантичний та аналітичний методи дослідження.

Результати дослідження та їх обговорення. Харчування $€$ одним 3 найважливіших фракторів, що впливають на стан здоров'я жінки під час вагітності та лактації. Адже в цей період відбуваються важливі фрізіологічні зміни в жіночому організмі, коли для нормального розвитку плода потрібне регулярне та збалансоване харчування 3 достатньою кількістю макро- і мікронутрієнтів. Адекватне харчування вагітних забезпечує правильний внутрішньоутробний розвиток плода, складні фрізіологічні перебудови в організмі жінки, пов'язані з перебігом вагітності, зумовлює їі працездатність і адаптацію до дії різних фракторів зовнішнього середовища [8, 9, 39]. 
Відомо, що маса тіла жінки впродовж усієї вагітності, і особливо в останні місяці, збільшується. Поступовий приріст маси тіла вимагає певного енергозабезпечення за рахунок продуктів харчового раціону. Все ще існують протиріччя щодо середнього рекомендованого споживання енергії під час вагітності. Існує думка, що в I триместpi (1-13 тиждень) вагітності харчування жінки практично не відрізняється від харчування здорових невагітних жінок. Добовий раціон повинен включати: 110 г білка, 75 г жиру і 350 г вуглеводів, при загальній калорійності - 2500-2700 ккал [16]. Однак $є$ дані про підвищення потреби в енергії на 100-150 ккал на добу вже у I триместрі вагітності, коли відбувається закладання і диференціювання органів плода. 3 5-го місяця вагітності потреба в енергії збільшується в середньому на 350 ккал на добу. Контролем правильності калорійності їжі $є$ маса тіла вагітної, приріст якої повинен бути не більше ніж 350 г на тиждень [3].

Контроль за масою тіла вагітних $€$ надзвичайно важливим, адже надлишкова маса тіла у поєднанні з порушенням ліпідного і вуглеводного обміну, артеріальною гіпертензією можуть несприятливо впливати на організм матері та плода. Якщо ці показники перевищують загальноприйняті в акушерській практиці, необхідно вносити зміни в режим харчування і фрізичної активності [28]. У разі надлишку маси тіла (понад 15 кг) у $15 \%$ вагітних жінок спостерігали слабкість пологової діяльності, переношування вагітності та великий плід, що ускладнює перебіг пологів і післяпологового періоду, пологовий травматизм матері та плода [27].

Для оцінки якості харчування одним з найпростіших і найвживаніших показників $€$ величина індексу маси тіла. Створений в США при Національній академії наук спеціальний Підкомітет 3 харчування вагітних рекомендує такі градації оцінок за IMT: знижена маса тіла - індекс, нижчий 19,8; нормальна маса тіла - індекс від 19,8 до 26,0; надлишкова маса - індекс від 26,0 до 29,0; ожиріння - індекс, вищий 29,0 [12].

При індексі маси тіла понад 30 кг/м² підвищується ризик розвитку таких патологічних станів, як прееклампсія, синдром затримки росту плода, макросомія, синдром раптової смерті плода [38]. Недостатність харчування або голодування теж недопустиме. У вагітних із дефіцитом маси тіла найчастіше спостерігали таку патологію, як самовільні викидні та передчасні пологи, а також народження дітей з низькою масою тіла порівняно $з$ іншими соматотипами вагітних [25].

Для запобігання надмірному приросту маси тіла необхідно дотримуватися раціонального харчування, у якому повинно бути правильне співвідношення компонентів їжі: білки - $15 \%$ (80-100 г на добу); жири - не більше 25-30\% (80-100 г на добу); вуглеводи - 55-60 \% добової калорійності (450-500 г на добу). Калорійність сніданку має становити приблизно 30-40 \% від добового раціону, обід - 50 \%, вечеря - $20 \%$. Необхідно споживати їжу 4-5 разів на день [28].
Під час вагітності жінкам надзвичайно важливо споживати достатню кількість білка, який необхідний для росту плода, плаценти, матки і молочних залоз. Низькобілкова дієта майбутніх матерів призводить до розвитку тяжких фрорм токсикозу, прееклампсії, анемії, блювоти і т. д. Дослідження на білих щурах виявили, що низькобілкова дієта сприяє народженню особин 3 малою масою тіла, уродженими вадами серця, тахікардією та підвищеним систолічним тиском [34]. Для профрілактики ускладнень вагітності $€$ рекомендація у II та III триместрах до норми білків додатково додавати 6 г на добу. Основними джерелами білків є нежирне біле м'ясо, риба, яйця, сир, нежирне молоко, кефір [28].

Жири є необхідним компонентом раціонального харчування. Але у харчуванні вагітних $є$ деякі особливості. Доцільно у раціон вводити переважну частку рослинних жирів, риби, морських продуктів, які $\epsilon$ джерелом надходження незамінних компонентів їжі - поліненасичених жирних кислот (ПНЖК), що позитивно впливають на розвиток центральної нервової системи, мозку, на фрормування структури та подальшого фрункціонування сітківки ока та інших важливих органів малюка $[12,36]$. Вони відіграють суттєву роль у профрілактиці захворювань серцево-судинної системи, печінки та інших органів і, зокрема, запобігають розвитку у вагітних можливих депресивних станів у III триместрі, які часто виникають при недостатності ПНЖК.

Основним джерелом енергії є вуглеводи, вони складають 55 \% добової енергетичної цінності раціону [3]. Але вагітним варто відмовитися від споживання простих вуглеводів (білого хліба, здоби, солодощів, макаронних виробів, цукру, варення), які швидко перетворюються в жири і відкладаються у вигляді зайвих кілограмів, сприяють виникненню ожиріння, підвищенню цукру в крові та розвитку гестаційного цукрового діабету, а також діабету в дитини після народження [16]. Основна кількість вуглеводів повинна надходити в організм у вигляді овочів, зелені, несолодких фрруктів і ягід. Помідори, огірки, моркву, кабачки, баклажани, шпинат та інші можна споживати необмежено.

Дуже корисно споживати їжу, багату на харчові волокна (або клітковину) [28]. Це дозволить запобігти закрепам, до яких схильні вагітні жінки, покращить моторну фрункцію кишечнику та нормалізує його мікрофрлору, сприятиме виведенню із організму надлишку холестерину і токсичних речовин. Джерелами харчових волокон є овочі та фррукти, також їх багато у хлібі з висівками і різних крупах та бобових.

Таким чином, для нормального приросту маси тіла під час вагітності та вчасного народження здорової дитини усім вагітним необхідно організовувати своє харчування згідно з основними принципами так званої «Тарілки здорового харчування», яка розроблена відповідно до рекомендацій Міністерства охорони здоров'я та Гарвардської школи громадського здоров'я, які полягають у такому: 
- 1/2 тарілки повинні становити овочі та фрукти. Чим більше овочів і чим більше їх різноманіття тим краще.

- 1/4 тарілки - цільні та неочищені зернові (ячмінь, зерна пшениці, вівсянка, гречка, неочищений рис) і продукти, виготовлені з них.

- 1/4 тарілки мають складати джерела здорового білка: риба, курка, квасоля, горіхи, яйця. Необхідно обмежити споживання червоного м'яса (яловичина, свинина, баранина) і уникати обробленого м'яса (бекон, сосиски, ковбаси).

- Жири є необхідною складовою раціону. Споживати потрібно корисні рослинні олії, такі як оливкова, рапсова, кукурудзяна, соняшникова, арахісова та інші для приготування їжі, салатів та овочів. Варто уникати шкідливих для організму трансжирів (з частково гідрованих олій), обмежувати вершкове масло.

- Необхідно пити воду, каву або чай, бажано без цукру. Необхідно відмовитися від солодких напоїв, бо їх вживання може призвести до збільшення маси тіла і ризику діабету 2 типу, серцевих захворювань та інших проблем. Корисно споживати одну або дві порції молока і молочних продуктів на день [33].

Велику увагу в харчуванні майбутніх матерів варто приділяти макро- і мікроелементам, які виконують в організмі вагітних багато різноманітних фрункцій, наприклад, регулюють синтез фрерментів, гормонів, вітамінів і низки білків, впливають на функції залоз внутрішньої секреції, процеси кровотворення, тканинного дихання, імунні реакції, поділ клітин, ріст, розмноження тощо [4, 28]. $Є$ інформація, що навіть збалансований раціон $€$ дефіцитним за основними вітамінами на 20-30\% [5]. Наприкінці вагітності у 50-92 \% жінок виявляли дефіцит двох і більше макро- або мікроелементів і вітамінів, що призводило до високого ризику ускладнень вагітності й пологів [9]. Встановлено, що в організмі майбутніх матерів найчастіше відзначали недостатність вітаміну С (у 60-70 \% жінок), заліза (у 20-40\%), кальцію (у 40-60\%), йоду (до $70 \%$ [33]. За іншими даними, найбільше виявляли дефіцит вітамінів $\mathrm{B}_{2} \mathrm{i}$ D (у 49-66 \% обстежених), а вітамін C - лише у 13-21\% вагітних [1, 9].

Недостатнє і неповноцінне харчування, особливо дефіцит амінокислот, вітамінів, поліненасичених жирних кислот, мінеральних речовин, може призводити не тільки до уроджених вад розвитку плода, але й до інших ускладнень гестаційного процесу, таких як прееклампсія, гестаційна гіпертензія, синдром затримки росту плода, передчасні пологи тощо [9, 10, 39]. Хронічний дефіцит вітамінів у їжі вагітної призводить до порушення обмінних процесів, процесів запліднення, імплантації, ембріон- і фетогенезу, пологів, лактації та післяпологової реабілітації дитини. Встановлено, що нестача таких вітамінів, як $A$, $\mathrm{E}, \mathrm{B}_{2}$ може зумовити запліднену яйцеклітину до загибелі в перші дні після зачаття, а виражена недостача вітамінів $\mathrm{A}, \mathrm{C}, \mathrm{B}_{2}$, PP, E викликає тератогенний і ембріотоксичний ефекти. Зниження забезпеченості вітамінами вагітних жінок $є$ одним із фракторів ризику високої захворюваності та смертності дітей раннього віку $[9,19]$.

До групи ризику за розвитком гіповітамінозів належать жінки, які мають дефріцит маси тіла або займаються важкою фрізичною працею, супутню патологію (гострі інфрекційні захворювання, патологію серцево-судинної системи, травного тракту, сечостатевої системи та інші), 3 багатоплідною вагітністю та повторно вагітні 3 інтервалом між пологами, меншим 2 років, підлітки та віком понад 35 років, вегетаріанки та які проживають в умовах жаркого клімату чи крайньої півночі. Гіповітамінози також розвиваються у тих вагітних, які курять, вживають алкоголь, наркотики або мешкають у несприятливих екологічних умовах, пов'язаних із промисловим забрудненням навколишнього середовища [4].

Оскільки в процесі вагітності плід інтенсивно набирає масу тіла, можна було б припустити, що потреби всіх вітамінів і мінералів однаково зростають зі збільшенням терміну гестації. Наприклад, в 1950-1960 рр. дозу кожного вітаміну під час вагітності просто збільшували приблизно в 1,5 раза. Але на початку XXI ст. за результатами різноманітних досліджень було встановлено більш диференційований і обґрунтований підхід до дозування окремих мікронутрієнтів [9]. За результатами низки досліджень, проведених Національним дослідним центром (США), Інститутом медицини (США) і Всесвітньою організацією охорони здоров'я (ВООЗ), було з'ясовано, що під час вагітності та грудного вигодовування потреба в кальції збільшувалася на 122-167\%, залізі на 187-454 \%, фролієвій кислоті - на 118-176\%, у той час як потреба в цинку, йодові, вітамінах $\mathrm{B}_{6}$ i $_{12}$ збільшувалася незначно - в інтервалі від 10 до $43 \%[5,23,39]$. Згідно з рекомендаціями ВООЗ щодо харчування вагітних (2016 р.), додаткове приймання вітамінів $\mathrm{B}_{6}$ та $\mathrm{D}$, цинку, полівітамінних добавок необхідне лише за показаннями. Додаткове приймання вітаміну А показано в місцевості, де спостерігали його дефіцит [41].

За останні роки значно підвищився інтерес до вітаміну D, який, на думку вчених, надзвичайно важливий не лише для репродуктивного здоров'я. Його нестача може не тільки погіршувати стан скелета у матері та плода, але також призвести до розвитку атеросклерозу, підвищувати ризик прееклампсії, спричинити інсулінорезистентність, гестаційний цукровий діабет, неонатальну гіпокальціємію, розвиток цукрового діабету I типу, метаболічного синдрому, захворювань серцево-судинної системи, підвищення рівня запальних маркерів у крові та макросомії [9, 32]. Результати досліджень свідчать про те, що приймання вітаміну D під час вагітності може знизити ризик передчасних пологів, появи високого тиску та народження дитини 3 низькою масою тіла. Для профілактики гіповітамінозу D вагітним потрібно вести активний спосіб життя та щодня декілька годин перебувати на свіжому повітрі [16]. 
Надзвичайно важливу роль у харчуванні вагітних жінок відіграє фолієва кислота або вітамін $\mathrm{B}_{9}$. Приймати фолієву кислоту рекомендовано ще за 2 місяці до зачаття у дозі 400-800 мг, а також під час I триместру вагітності та на пізніх термінах теж [36]. Десріцит вітаміну призводить до дефекту розвитку нервової трубки плода, уроджених вад серця, гіпотрофрії плода та синдрому Дауна [39]. Джерелами фролієвої кислоти для вагітних жінок можуть бути як продукти рослинного (зелені листові овочі, цитрусові, волоські горіхи, бобові, пшеничні проростки і дріжджі, злаки, висівки, гречана і вівсяна крупи), так і тваринного походження (печінка, яловичина, баранина, свинина, домашня птиця, яйця, молоко і молочні продукти, риба) [13].

На сьогодні не викликає жодних сумнівів важлива роль мікроелементів у різноманітних фрункціях організму вагітної жінки. Порушення їх вмісту та балансу в плода й немовляти, особливо на фоні затримки внутрішньоутробного розвитку, через незрілість органів і систем можуть проявлятися розвитком захворювань, ознаками дезадаптації, порушенням фрізичного та психічного розвитку, уродженими аномаліями [9]. Дефріцит у вагітних мікроелементів магнію, кальцію, міді, цинку, заліза може викликати самовільне переривання вагітності, розвиток уроджених вад плода, недостатність селену може призвести до імунодефіциту, а дисбаланс співвідношення магнію і кальцію - до розвитку кальцинозу плаценти 3 фрормуванням плацентарної недостатності [6, 14].

Залізо - один із найважливіших мікроелементів для вагітних жінок і тих, які годують груддю [37]. При його дефріциті розвивається залізодефіцитна анемія, яка поширена як у розвинених країнах (у 17-20 \% жінок), так і в країнах, що розвиваються (30-49\% вагітних) [39]. Ця хвороба викликає гіпоксію та затримку розвитку плода, слабкість пологової діяльності у вагітної жінки, анемію та серцево-судинні захворювання у новонароджених $[7,29]$. Дотримання здорової та збалансованої дієти під час вагітності, споживання достатньої кількості м'яса, печінки, риби, домашньої птиці, бобових та листової зелені допоможе підтримати рівень заліза, необхідний для здоров'я матері та дитини.

Цинк відіграє важливу роль в організмі вагітної жінки, оскільки необхідний для нормального проходження всіх фраз дроблення заплідненої яйцеклітини до її фріксації в порожнині матки, знижує ймовірність передчасних пологів, забезпечує правильний розвиток плода. Споживання цинковмісних продуктів необхідно починати при плануванні вагітності. Це підготує яйцеклітини до дозрівання фолікул і запліднення, мінімізує ризик самовільного викидня і забезпечує нормальне фрормування плода. Продукти, багаті на цинк: м'ясо птиці, свинина, риба, зернові, морква, горіхи, горох [15].

Недостатність приймання йоду вагітною призводить до підвищеного ризику перинатальної смертності та неонатального гіпотиреоїдизму, може спричинити виникнення спонтанного аборту, збільшує ризик смертності немовлят, уроджених вад розвитку, десектів центральної нервової системи новонародженого [35]. У I триместрі під впливом тиреоїдних гормонів у плода фрормуються найважливіші структури головного мозку (кора, мозолисте тіло, підкіркові ядра, смугасте тіло, субарахноїдальні шляхи), очі, лицевий череп, легенева тканина. У II триместрі фрормуються нейрони церебральної кори і базальних гангліїв, диференціюється завиток і фрормується слух. У III триместрі остаточно диференціюється кора головного мозку, дитина отримує здатність до асоціативного й абстрактного мислення [30]. Потреба в йодові при настанні вагітності зростає до 150-250 мкг на добу [19, 42]. Світова практика показала, що найбільш ефективним, загальнодоступним і безпечним засобом масової профрілактики йододесіцитних захворювань $€$ загальне споживання йодованої кухонної солі. Також кожна вагітна жінка у харчуванні може використовувати продукти, багаті на йод (морепродукти), для гарантії надходження необхідної кількості йоду та забезпечення нормальної секреції гормонів щитоподібної залози для нормального розумового розвитку дитини [18].

Кальцій - найважливіший елемент для скорочення м'язів, у тому числі таких, як серце або матка. Він вкрай необхідний для нормального функціонування системи згортання крові, повноцінної роботи нирок, росту й розвитку кісткової системи [9]. Плоду, який росте, кальцій потрібен як для росту кісток і зубів, так і для формування всіх тканин організму, включаючи нервові клітини, внутрішні органи, сполучну тканину, очі, шкіру, волосся і нігті. Добова норма кальцію під час вагітності та лактації - 1500-2000 мг на день. Головне джерело кальцію - кисломолочні продукти, злаки та овочі.

Десріцит магнію у вагітних жінок спостерігали досить часто (від 16 до $43 \%$ обстежених) $[6,20,26]$. Ознаками дефіциту магнію $€$ швидка втомлюваність, перепади настрою, безсоння, немотивована дратівливість, плаксивість, розвиток депресивних станів, фобій, зниження уваги, пам'яті, порушення свідомості, виникнення судомних нападів, розвиток набряків, підвищення артеріального тиску [2, 6, 26]. Найнебезпечнішим проявом гіпомагніємії у вагітних є загроза викидня впродовж усієї вагітності, висока частота фрормування прееклампсії, передчасні пологи, біль у спині, попереку, в ділянці кістково-м'язового апоневрозу тазового відділу [20]. Добова потреба в магнію під час вагітності зростає до 340-355 мг. До продуктів, що містять магній, належать мигдаль, соєве борошно, бобові, какао, волоський горіх, злакові, шпинат, броколі та ін.

\section{Висновки}

Проведений аналіз літературних джерел дає можливість стверджувати, що материнський організм під час вагітності є єдиним джерелом усіх харчових речовин для плода. Під час підготов- 
ки до вагітності, самої вагітності та грудного вигодовування дитини потреба жіночого організму у вітамінах, мікро- і макроелементах зростає. Особливо підвищується потреба в таких мікронутрієнтах, як залізо, йод, фролієва кислота, кальцій, магній, цинк, вітамін D тощо. Тому раціональне харчування, збалансоване за всіма харчовими продуктами, 3 необхідною кількістю макро- і мікронутрієнтів, є одним 3 найважливіших фракторів, необхідних для підтримки здоров'я і забезпечення стійкості організму вагітних жінок до негативного впливу зовнішнього середовища, який дозволить знизити ризик розвитку перинатальної патології, дитячої смертності, зменшити частоту недоношеності та уроджених вад розвитку.

Перспективи подальших досліджень полягають у вивченні та аналізі харчування вагітних жінок в Тернопільській області.

\section{Список літератури}

1. Бойчук A. В. Десріцит вітаміну D і вагітність / А. В. Бойчук, Т. О. Буднік // Актуальні питання педіатрії, акушерства та гінекології. - 2016. - № 2. - С. 36-39.

2. Буданов П. В. Актуальные проблемы невынашивания беременности на фоне дефицита магния / П. В. Буданов // Гинекология. - 2010. - Т. 12, № 5. - С. 24-29.

3. Гігієна харчування з основами нутриціології : підручник для студентів вищих навчальних медичних закладів IIIIV рівнів акредитації, лікарів-інтернів і курсантів інституту удосконалення лікарів / В. І. Ципріян [та ін.] ; за ред. В. І. Ципріяна. - К. : Здоров'я, 1999. - 568 с.

4. Громова О. А. Перспективы витаминной и минеральной коррекции у беременных : лекции для практикующих врачей / О. А. Громова // Человек и лекарство : XII Национальный конгресс, 2004.

5. Громова О. А. Потриместровый подход к назначению витаминно-минеральных комплексов на основе систематического анализа биологической значимости витаминов и микроэлементов в системе мать-плацентаплод / О. А. Громова, В. Н. Серов, И. Ю. Торшин // Гинекология. - 2010. - Т. 12, № 6. - С. 115-122.

6. Громова О. А. Магний и «болезни цивилизации» / О. А. Громова, И. Ю. Торшин. - М., 2018. - 790 с.

7. Дворецкий Л. И. Клинические рекомендации по лечению больных железодесицитной анемией / Л. И. Дворецкий // Русский медицинский журнал. - 2004. - Т. 12, № 14. - С. 893-897.

8. Доброхотова Ю. Э. Рациональная витаминотерапия в группах риска по развитию акушерских осложнений / Ю. Э. Доброхотова, Э. М. Джобава, А. В. Степанян // Гинекология. - 2011. - № 1 (13). - С. 53-55.

9. Жемела Н. І. Вплив вітамінів та мікроелементів на перебіг вагітності / Н. І. Жемела // Здоровье женщины. - 2013. № 3 (79). - C. 44-51.

10. Зазерская И. Е. Витамин D и гестационные риски / И. Е. Зазерская, Е. С. Шелепова, Л. В. Ширинян // Остеопороз и остеопатии. - 2016. - № 2 (19). - С. 48.

11. Інфрормаційна магістраль - здоров'ю жінок : програма охорони репродуктивного здоров'я, репродуктивних прав жінок та попередження передракових та ракових захворювань жіночої статевої системи // Основи гігієни та праці. 2001. - № 3. - C. 34-58.

12. Камінський В. В. Особливості харчування вагітних (огляд літератури) / В. В. Камінський, О. В. Швець, О. І. Гервазюк // Збірник наукових праць Асоціації акушерів-гінекологів України. - 2015. - Вип. 2. - С. 117-122.

13. Карнаух Э. В. Фолиевая кислота в жизни человека [Электронный ресурс] // Э. В. Карнаух, М. В. Плугатарева // European student scientific journal. - 2014. - № 2. - Режим доступа : http://sjes.esrae.ru/21-231.

14. Коденцова В. М. Витаминно-минеральные комплексы для беременных и кормящих женщин: обоснование состава и доз / В. М. Коденцова, М. В. Гмошинская, О. А. Вржесинская // Репродуктивное здоровье детей и подростков. - 2015. - № 3. - С. 73-96.

15. Коржинський Ю. С. Роль цинку в нормі та при патології / Ю. С. Коржинський, А. Є. Лісний // Здоров'я дитини. 2009. - № 1 (16). - С. 52-57.

16. Королюк А. О. Сучасний погляд на особливості харчування вагітних / А. О. Королюк, Ю. В. Цисар // Медичний фрорум. - 2020. - № 21 (21). - С. 27-31.

17. Костюк Ю. С. Особливості харчування вагітних жінок і молодих матерів / Ю. С. Костюк // Проблеми фрормування здорового способу життя у молоді : зб. матеріалів X Всеукр. наук.-практ. конф. молодих учених та студентів 3 міжнар. участю, Одеса, 29 верес. - 1 жовт. 2017 р. / Одес. нац. акад. харч. технологій ; гол. ред. Б. В. Єгоров. Одеса, 2017. - С. 158-159.

18. Кравченко В. І. Біологічна роль йоду та йодна недостатність як патогенетичний фрактор виникнення тиреоїдної патології у вагітних та її профрілактика / В. І. Кравченко, Б. К. Медведєв // Міжнародний ендокринологічний журнал. 2018. - № 2 (14). - С. 111-118.

19. Льовкіна О. Л. Сучасний погляд лікаря акушер-гінеколога на особливості раціону вагітних / О. Л. Льовкіна // Вісник Вінницького національного медичного університету. - 2021. - № 1 (25). - С. 171-174.

20. О диагностике дефицита магния. Часть 1 / О. А. Громова, А. Г. Калачёва, И. Ю. Торшин и др. // Архивъ внутренней медицины. - 2014. - № 2. - С. 5-10.

21. Паєнок О. С. Вплив вітаміну D на перебіг вагітності, розвиток плода та здоров'я дітей у постнатальному періоді / О. С. Паєнок, В. А. Маслянко, І. В. Паньків // Міжнародний ендокринологічний журнал. - 2018. - № 7 (14). C. 694-704. 
22. Підтримка імунітету під час вагітності - спокій матері та здоров'я майбутньої дитини [Електронний ресурс] // Здоров'я України. - 2021. - № 1 (42). - С. 27. - Режим доступу : https://health-ua.com/article/64771-pdtrimka-muntetupd-chas-vagtnost-spokj-mater-tazdorovya-majbutno-ditini.

23. Прилепская В. Н. Поливитаминные препараты и нутриенты: роль в восполнении десицита фолиевой кислоты и йода у беременных / В. Н. Прилепская, А. В. Ледина // Гинекология. - 2010. - № 3 (12). - С. $18-19$.

24. Проблема мікроелементів у харчуванні населення України та шляхи її вирішення / Н. С. Корзун, І. П. Козярин, А. М. Парац [та ін.] // Проблеми харчування. - 2007. - № 1. - С. 5-11.

25. Савкина Е. А. Влияние дефицита массы тела на исход беременности / Е. А. Савкина, О. Ю. Сычева // Здоровье и образование в XXI веке : электронный сборник научных трудов. - 2010. - № 9. - С. 465-466.

26. Сенчук А. Я. Магній. Біологічна роль і застосування в акушерстві та гінекології : навч. посіб. / А. Я. Сенчук. - К. : Фенікс, 2018. - 104 с.

27. Старостина Е. Г. Принципы рационального питания в терапии ожирения. Часть I / Е. Г. Старостина // Кардиология. - 2001. - № 5. - С. 94-99.

28. Тарасенко К. В. Раціональне харчування вагітних з надмірною вагою тіла як складова здорового способу життя / К. В. Тарасенко, А. М. Громова, Л. А. Нестеренко // Актуальні проблеми сучасної медицини. - 2015. - Т. 15, Вип. 2. C. $43-46$.

29. Alwan N. Maternal iron status in pregnancy and long-term health outcomes in the offspring / N. Alwan, H. Hamamy // J. Pediatr. Genet. - 2015. - Vol. 4 (2). - P. 111-123.

30. Direct iodine supplementation of infants versus supplementation of their breastfeeding mothers: a double-blind, randomised, placebocontrolled trial / R. R. Bouhouch, S. Bouhouch, M. Cherkaoui [et al.] // Lancet Diabetes Endocrinol. 2014. - Vol. 2 (3). - P. 197-209.

31. Diet in pregnancy - more than food / H. Danielewicz, G. Myszczyszyn, A. Dębińska [et al.] // European Journal of Pediatrics. - 2017. - Vol. 176 (12). - P. 1573-1579.

32. Holmes V. A. Vitamin D deficiency and insufficiency in pregnant women: a longitudinal study / V. A. Holmes, M. S. Barnes // Br. J. Nutr. - 2009. - Vol. 102 (6). - P. 876-881.

33. https://moz.gov.ua/article/health/porivnjajte-svoju-izhu-z-tarilkoju-zdorovogo-harchuvannja

34. Institute of Medicine of the National Academies. (2015). Dietary Reference Intakes: Macronutrients Nutrient. Washington, D.C.

35. lodine supplementation for women during the preconception, pregnancy and postpartum period / K. B. Harding, J. P. Peña-Rosas, A. C. Webster [et al.] // Cochrane Database Syst. Rev. - 2017. - Vol. 3 (3). - CD011761.

36. Maternal antenatal multiple micronutrient supplementation for longtermhealth benefits in children: a systematic review and meta-analysis / D. Devakumar, C. H. Fall, H. S. Sachdev [et al.] // BMC Medicine. - 2016. - Vol. $14,90$.

37. Maternal diet and nutrient requirements in pregnancy and breastfeeding. An Italian consensus document / F. Marangoni, I. Cetin, E. Verduci [et al.] // Nutrients. - 2016. - Vol. 8 (10). - P. 629.

38. Maternal obesity and neonatal mortality according to subtypes of preterm birth / E. A. Nohr, M. Vaeth, B. H. Bech [et al.] // Obstet Gynecol. - 2007. - Vol. 110 (5). - P. 1083-1109.

39. Micronutrient deficiencies in pregnancy worldwide: health effects and prevention / A. D. Gernand, K. J. Schulze, C. P. Stewart [et al.] // Nat. Rev. Endocrinol. - 2016. - Vol. 12 (5). - P. 274-289.

40. Nutrition During Pregnancy, Lactation and Early Childhood and its Implications for Maternal and Long-Term Child Health: The Early Nutrition Project Recommendations / B. Koletzko, K. M. Godfrey, L. Poston [et al.] // Ann Nutr Metab. 2019. - Vol. 74. - P. 93-106.

41. WHO (2016) WHO recommendations on antenatal care for a positive pregnancy experience. World Health Organization, Geneva.

42. Zimmermann M. B. Iodine deficiency and thyroid disorders / M. B. Zimmermann, K. Boelaert // Lancet Diabetes Endocrinol. - 2015. - Vol. 3 (4). - P. 286- 295.

\section{References}

1. Boychuk, A.V., \& Budnik, T.O. (2016). Defitsyt vitaminu D i vahitnist. [Deficiency of vitamin D and pregnancy] Aktualni pytannia pediatrii, akusherstva ta hinekolohii - Current Issues of Pediatrics, Obstetrics and Gynecology, 2, 36-39. Retrieved from: https://doi.org/10.11603/24116-4944.2016.2.6852 [in Ukrainian].

2. Budanov, P.V. (2010) Aktulnyie problemyi nevyinashivaniya beremennosti na fone defitsita magniya. [Actual problems of miscarriage in the presence of magnesium deficiency] Ginekologiya - Gynecology., 5(1), 28-32 [in Russian].

3. Tsypriian, V.I. (1999). Hihiiena kharchuvannia z osnovamy nutrytsiolohii [Food hygiene with the basics of nutrition] : (Ed.) V. I. Tsypriian. K. : Zdorovia [in Ukrainian].

4. Gromova, O.A. (2004) Perspektivy vitaminnoy i mineralnoy korrektsii u beremennykh. Lektsii dlya praktikuyushchikh vrachey. [Prospects for vitamin and mineral correction in pregnant women. Lectures for medical practitioners] XII Natsionalnyy kongress «Chelovek i lekarstvo» - XII National Congress «Man and Medicine» [ in Russian].

5. Gromova, O.A., Serov, V.N. \& Torshin, I.Yu.( 2010) Potrimestrovyy podkhod k naznacheniyu vitaminno-mineralnykh kompleksov na osnove sistematicheskogo analiza biologicheskoy znachimosti vitaminov i mikroelementov $v$ sisteme mat-platsenta-plod. [A per-trimester approach to the appointment of vitamin-mineral complexes based on a systematic analysis of the biological significance of vitamins and trace elements in the mother-placenta-fetus system] Ginekologiya Gynecology, 6, 24-33 [ in Russian].

6. Gromova, O.A. \& Torshin, I.Yu. (2018) Magniy i «bolezni tsivilizatsii»»[ Magnesium and "diseases of civilization"]. Moscow [in Russian]. 
7. Dvoreckij, L.I. (2004) Klinicheskie rekomendacii po lecheniyu bolnykh zhelezodeficitnoj anemiej [Clinical guidelines for the treatment of patients with iron deficiency anemia] Russkij medicinskij zhurnal.- Russian Medical Journal, 14(12), 893897 [in Russian].

8. Dobrokhotova, Yu.E., Jobava, E.M., \& Stepanyan, A.V. (2011). Ratsionalnaya vitaminoterapiya v gruppakh riska po razvitiyu akusherskikh oslozhneniy [Rational vitamin therapy in risk groups for the development of obstetric complications]. Ginekologiya - Gynecology, 1 (13), 53-55 [in Russian].

9. Zhemela, N.I. (2013). Vplyv vitaminiv ta mikroelementiv [Influence of vitamins and microelements]. Zdorove zhenshchynyWomen's Health, 3(79), 44-51. [in Ukrainian]

10. Zazerskaya, I.E., Shelepova, E.S., Shirinyan, L.V. \& Kuznetsova, L.V. (2016) Vitamin D i gestatsionnye riski [Vitamin D and gestation risks]. Osteoporosis and Osteopathy - Osteoporosis And Bone Diseases, 19(2), 48-48 [in Russian].

11. (2001). «Informatsiyna mahistral - zdorovyu zhinok». Prohrama okhorony reproduktyvnoho zdorovya, reproduktyvnykh prav zhinok ta poperedzhennya peredrakovykh ta rakovykh zakhvoryuvan zhinochoyi statevoyi systemy ["Information Highway - Women's Health". Program of reproductive health, women's reproductive rights and prevention of precancerous and cancerous diseases of the female reproductive system] Osnovy hihiyeny ta pratsi - Fundamentals of Hygiene and Labor, 3, 34-58. [in Ukrainian].

12. Kaminsky, V.V., Shvets, O.V. \& Gervazyuk, O.I. (2015) Osoblyvosti kharchuvannya vahitnykh (ohlyad literatury) Zbirnyk naukovykh prats Asotsiatsiyi akusheriv-hinekolohiv Ukrayiny / pod. red. Zaporozhan V.M., Kaminskyy V.V., Borys O.M. [Peculiarities of nutrition of pregnant women (literature review). Collection of scientific works of the Association of Obstetricians and Gynecologists of Ukraine / under. ed. Zaporozhyan V.M., Kaminsky V.V., Boris O.M. - K.: Polihrafiya «YUSTON» [in Ukrainian].

13. Karnaukh, E.V. \& Plugatareva, M.V. (2014) Folievaya kislota v zhizni cheloveka [Folic acid in human life] European Student Scientific Journal, 2. Retrieved from: http://sjes.esrae.ru/21-231 [in Russian].

14. Kodentsova, V.M., Gmoshinskaya, M.V. \& Vrzhesinskaya, O.A. (2015). Vitaminno-mineralnyye kompleksy dlya beremennykh i kormyashchikh zhenshchin: obosnovaniye sostava i doz. [Vitamin and mineral complexes for pregnant and lactating women: substantiation of the composition and doses] Reproduktivnoye zdorovye detey i podrostkov. Reproductive Health of Children and Adolescents, 3 (62), 73-96 [in Russian].

15. Korzhynskyi, Yu.S. \& Lisnyi, A.le. (2009). Rol tsynku v normi ta pry patolohii [Role of zinc in normal and in pathology] Zdorovia dytyny - Child Health, 1 (16), 52-57 [in Ukrainian].

16. Korolyuk, A.A. \& Tsisar, Yu.V. (2020). Suchasnyy pohlyad na osoblyvosti kharchuvannya vahitnykh [Modern view on the peculiarities of nutrition of pregnant women]. Medychnyy forum - Medical Forum, 21 (21), 27-31 [in Ukrainian].

17. Kostyuk, Yu.S. (2017). Osoblyvosti kharchuvannya vahitnykh zhinok i molodykh materiv [Features of nutrition of pregnant women and young mothers] Problemy formuvannya zdorovoho sposobu zhyttya u molodi : $z b$. materialiv $X$ Vseukr. nauk.-prakt. konf. molodykh uchenykh ta studentiv z mizhnar. Uchastyu - Problems of forming a healthy lifestyle in youth: collection. materials $X$ All-Ukrainian. scientific-practical conf. young scientists and students of international. participation, Odesa, (pp. 158-159) [in Ukrainian].

18. Kravchenko, V.I. \& Medvedyev, B.K. (2018). Biolohichna rol yodu ta yodna nedostatnist yak patohenetychnyy faktor vynyknennya tyreoyidnoyi patolohiyi u vahitnykh ta yiyi profilaktyka.[ Biological role of iodine and iodine deficiency as a pathogenetic factor in the occurrence of thyroid pathology in pregnant women and its prevention]. Mizhnarodnyy endokrynolohichnyy zhurnal - International Journal of Endocrinology, 2(14), 111-118 [in Ukrainian].

19. Levkina, O.L. (2021). Suchasnyy pohlyad likarya akusher-hinekoloha na osoblyvosti ratsionu vahitnykh [Modern view of obstetrician-gynecologist on the peculiarities of the diet of pregnant women] Visnyk Vinnytskoho natsionalnoho medychnoho universytetu - Bulletin of Vinnytsia National Medical University, 1 (25), 171-174 [in Ukrainian].

20. Gromova, O.A., Kalachova, A.G., Torshin, I.Yu., Grustlivaya, U.Ye., Prozorova, N.V., Yegorova, Ye.Yu., Grishina, TR. (2014) O diagnostike defitsita magniya. Chast 1 [About the diagnosis of magnesium. Part 1] Arkhiv vnutrenney meditsiny Archive of Internal Medicine. 2(16), 5-10. Retrieved from: https://doi.org/10.20514/2226-6704-2014-0-2-5-10 [in Russian]. 21. Paenok, O.S., Maslyanko, V.A. \& Pankiv, I.V. (2018). Vplyv vitaminu D na perebih vahitnosti, rozvytok ploda ta zdorov"ya ditey u postnatal'nomu periodi [Influence of vitamin D on pregnancy, fetal development and children's health in the postnatal period] Mizhnarodnyy endokrynolohichnyy zhurnal - International Journal of Endocrinology, 7(14), $694-704$ [in Ukrainian]. 22. (2021). Pidtrymka imunitetu pid chas vahitnosti - spokiy materi ta zdorovya maybutnoyi dytyny [Support of immunity during pregnancy - the peace of the mother and the health of the unborn child] Akusherstvo, Hinekolohiya, ReproduktolohiyaObstetrics, Gynecology, Reproductology, 1(42), 27. Retrieved from: https://health-ua.com/article/64771-pdtrimka-muntetupd-chas-vagtnost-spokj-mater-tazdorovya-majbutno-ditini [in Ukrainian].

23. Prilepskaya, V.N. \& Ledina, A.V. (2010) Polivitaminnyye preparaty i nutriyenty: rol v vospolnenii defitsita foliyevoy kisloty i yoda u beremennykh [Multivitamins and nutrients: the role in replenishing the deficiency of folic acid and iodine in pregnant women] Ginekologiya - Gynecology, 3 (12), 18-19 [in Russian].

24. Korzun, V.N., Kozyarin, I.P., Parats, A.M., Shkuro, V.V., Bolokhnova, T.V. \& Tsybenko, T.O. (2007). Problema mikroelementiv u kharchuvanni naselennya Ukrayiny ta shlyakhy yiyi vyrishennya [The problem of trace elements in the nutrition of the population of Ukraine and ways to solve it]. Problemy kharchuvannya - Problems of nutrition, 1, 5-11 [in Ukrainian].

25. Savkina, Ye.A. \& Sycheva, O.Yu. (2010). Vliyaniye defitsita massy tela na iskhod beremennosti [Influence of body weight deficit on pregnancy outcome] Elektronnyy sbornik nauchnykh trudov «Zdorovye i obrazovaniye v XXI Veke»Electronic collection of scientific papers "Health and Education in the XXI Century", 9, 465-466 [in Russian].

26. Senchuk, A. Ya. (2018). Mahniy. Biolohichna rol i zastosuvannya vakusherstvi ta hinekolohiyi: navch. posib. [Magnesium. Biological role and application in obstetrics and gynecology: textbook] .K.: «Feniks» [in Ukrainian]. 
27. Starostyna, E.H. (2001.) Pryntsypy ratsyonalnoho pytaniya v terapyy ozhyrenyya. Chast I. [Principles of nutrition in the treatment of obesity. Part I.] Kardiolohiya. - Cardiology, 5, 94-99 [in Russian].

28. Tarasenko, K.V., Hromova, A.M, Nesterenko, L.A., \& Mamontova, T.V. (2015). Ratsionalne kharchuvannya vahitnykh z nadmirnoyu vahoyu tila yak skladova zdorovoho sposobu zhyttya [Rational nutrition of pregnant women with excess body weight as a component of a healthy lifestyle] Aktualni problemy suchasnoyi medytsyny. - Actual Problems of Modern Medicine, 2(15), 43-46. Retrieved from: http://nbuv.gov.ua/UJRN/apsm_2015_15_2_12 [in Ukrainian].

29. Alwan, N.A., \& Hamamy, H. (2015). Maternal Iron Status in Pregnancy and Long-Term Health Outcomes in the Offspring. Journal of Pediatric Genetics, 4(2), 111-123. Retrieved from: https://doi.org/10.1055/s-0035-1556742.

30. Bouhouch, R.R., Bouhouch, S., Cherkaoui, M., Aboussad, A., Stinca, S., Haldimann, M., Andersson, M., \& Zimmermann, M.B. (2014). Direct iodine supplementation of infants versus supplementation of their breastfeeding mothers: a doubleblind, randomised, placebo-controlled trial. The Lancet. Diabetes \& Endocrinology, 2(3), 197-209. Retrieved from:https:// doi.org/10.1016/S2213-8587(13)70155-4.

31. Danielewicz, H., Myszczyszyn, G., Dębińska, A., Myszkal, A., Boznański, A., \& Hirnle, L. (2017). Diet in pregnancymore than food. European Journal of Pediatrics, 176(12), 1573-1579. Retrieved from:https://doi.org/10.1007/s00431-0173026-5.

32. Holmes, V.A., Barnes, M.S., Alexander, H. McFaul, P., \& Wallace, J.M. (2009). Vitamin D deficiency and insufficiency in pregnant women: a longitudinal study. The British Journal of Nutrition, 102(6), 876-881. Retrieved from:https://doi. org/10.1017/S0007114509297236.

33. https://moz.gov.ua/article/health/porivnjajte-svoju-izhu-z-tarilkoju-zdorovogo-harchuvannja

34. Institute of Medicine of the National Academies. (2015). Dietary Reference Intakes: Macronutrients Nutrient. Washington, D.C.

35. Harding, K.B., Peña-Rosas, J.P., Webster, A.C., Yap, C.M., Payne, B.A., Ota, E., \& De-Regil, L.M. (2017). Iodine supplementation for women during the preconception, pregnancy and postpartum period. The Cochrane Database of Systematic Reviews, 3(3), CD011761. Retrieved from: https://doi.org/10.1002/14651858.CD011761.pub2.

36. Devakumar, D., Fall, C.H., Sachdev, H.S., Margetts, B M., Osmond, C., Wells, J.C., Costello, A., \& Osrin, D. (2016). Maternal antenatal multiple micronutrient supplementation for long-term health benefits in children: a systematic review and meta-analysis. BMC Medicine, 14, 90. Retrieved from: https://doi.org/10.1186/s12916-016-0633-3.

37. Marangoni, F., Cetin, I., Verduci, E., Canzone, G., Giovannini, M., Scollo, P., Corsello, G., \& Poli, A. (2016). Maternal Diet and Nutrient Requirements in Pregnancy and Breastfeeding. An Italian Consensus Document. Nutrients, 8(10), 629. Retrieved from: https://doi.org/10.3390/nu8100629.

38. Nohr, E.A., Vaeth, M., Bech, B.H., Henriksen, T.B., Cnattingius, S., \& Olsen, J. (2007). Maternal obesity and neonatal mortality according to subtypes of preterm birth. Obstetrics and Gynecology, 110(5), 1083-1090. Retrieved from: https:// doi.org/10.1097/01.AOG.0000286760.46679.f8.

39. Gernand, A.D., Schulze, K.J., Stewart, C.P., West, K.P., Jr, \& Christian, P. (2016). Micronutrient deficiencies in pregnancy worldwide: health effects and prevention. Nature reviews. Endocrinology, 12(5), 274-289. Retrieved from: https://doi.org/10.1038/nrendo.2016.37.

40. Koletzko, B., Godfrey, K.M., Poston, L., Szajewska, H., van Goudoever, J.B., de Waard, M., Brands, B., Grivell, R.M., Deussen, A R., Dodd, J.M., Patro-Golab, B., Zalewski, B.M., \& Early Nutrition Project Systematic Review Group (2019). Nutrition During Pregnancy, Lactation and Early Childhood and its Implications for Maternal and Long-Term Child Health: The Early Nutrition Project Recommendations. Annals of Nutrition \& Metabolism, 74(2), 93-106. Retrieved from: https:// doi.org/10.1159/000496471.

41. WHO (2016) WHO recommendations on antenatal care for a positive pregnancy experience. World Health Organization, Geneva.

42. Zimmermann, M.B., \& Boelaert, K. (2015). Iodine deficiency and thyroid disorders. The Lancet. Diabetes \& Endocrinology, 3(4), 286-295. Retrieved from: https://doi.org/10.1016/S2213-8587(14)70225-6.

\section{THE IMPORTANCE OF RATIONAL DIET FOR THE HEALTH OF PREGNANT WOMEN}

\section{O. V. Lototska, O. Ye. Gavlich}

I. Horbachevsky Ternopil National Medical University, Ternopil, Ukraine

Purpose: to analyze the literature on the peculiarities of nutrition of pregnant women and determine its role in preventing the development of complications of pregnancy and the health of the unborn child.

Materials and Methods. An analysis of literature sources on the peculiarities of nutrition of pregnant women. Bibliosemantic and analytical research methods are used.

Results. For the normal development of the fetus requires regular and rational nutrition of the expectant mother with a sufficient amount of macro-and micronutrients. The need for such nutrients as iron, iodine, folic acid, calcium, magnesium, zinc, vitamins D, etc. is especially increasing. Insufficient and poor nutrition can lead not only to congenital malformations of the fetus, but also to other complications of the gestational process, such as preeclampsia, gestational hypertension, fetal growth retardation syndrome, premature birth, and so on. There are still controversies in the scientific literature regarding the average recommended energy intake during pregnancy, the amount of additional intake of vitamins and other macro- and micronutrients. To normalize nutrition, all pregnant women need to organize their diet according to the basic principles of the so-called «Plate of Healthy Eating», which was developed according to the recommendations of the Department of Health and Harvard School of Public Health. 
Conclusions. A rational diet, balanced with all foods, with the necessary amount of macro- and micronutrients, is one of the most important factors necessary to maintain the health and resistance of pregnant women to the negative effects of the environment, which reduces the risk of perinatal pathology, infant mortality, reduces the incidence of prematurity and congenital malformations.

KEY WORDS: nutrition of pregnant women; rational diet; nutrient deficiency; prevention of pregnancy complications.

Рукопис надійшов до редакції 30.08.2021 p.

Відомості про авторів:

Лотоцька Олена Володимирівна - доктор медичних наук, професор кафедри загальної гігієни та екології Тернопільського національного медичного університету імені І. Я. Горбачевського МОЗ України; тел.: +38(0352) 52-47-88.

Гавліч Оксана Євгенівна - магістрант зі спеціальності «Громадське здоров'я» Тернопільського національного медичного університету імені І. Я. Горбачевського МОЗ України; тел.: +38(098) 933-84-05. 